\title{
Administration, Scoring \& Interpretation of Interest Inventory- A Study on 10th Class Students (Jaipur)
}

\author{
Vaishali Joshi $^{1 *}$, Shubham Joshi ${ }^{2}$, Dr. Manju Joshi ${ }^{3}$
}

\section{ABSTRACT}

The present study on Administration, Scoring and Interpretation of Interest Inventory: A study on 10th class students (Jaipur) was conducted in 2014-2015 in Khonagorian, Jaipur. The sample consisted of 10 secondary school children from 10th class. Data was collected through Interest Inventory. Interest Inventory developed by S. Chatterji’s (non-verbal preference records-962). This a Non-language tests of interest to measure vocational interest on ten different areas. They are Fine Arts, Literary Work, Scientific, Medical, Agricultural, Mechanical/Technical, Crafts, Out Door, Sports, and Household Work. The raw scores were converted in stanine scores with the help of manual norms. Interpretation of result was done in three ways 1) Individual Interest 2) Group Interest 3) Area wise. The result revealed that interest of the group often student's varies from one interest area to another. It shows the individual differences.

Keywords: Administration, Scoring, Interpretation, Interest Inventory-, 10th Class Students, Jaipur

In school every student has different types of interests, likes and dislikes. When student complete education up to 10 class at school and he leave the school, then he seek to take admission for further study and from this point problems come in existence like what type of area ( educational, vocational , technical etc.) he should opt. At this stage in private school principle and teachers examine many types of tests as per child's interest in different area. Psychologists have witnessed that each and every individual has got own cult of personality with varying degree of interest. Interest indicates the mode of life of the individual. It is the interest which helps to bring about the selectivity. It is the interest which has great incentive to attention.

Various definition by different authors also indicated it like "Interest is a stable quality of an individual” by M.C. Dougall. "Interest is a disposition in its dynamic aspect.” by Drever and

\footnotetext{
${ }^{1}$ Research Scholar, Department of Business Administration, University of Rajasthan, Jaipur, India

${ }^{2}$ Research Scholar, Department of Business Administration, University of Rajasthan, Jaipur, India

${ }^{3}$ Assistant Professor, Department of Education (Commerce) Jaipur National University, Jaipur, India

*Responding Author

(C) 2016 V Joshi, S Joshi, M Joshi; licensee IJIP. This is an Open Access Research distributed under the terms of the Creative Commons Attribution License (http://creativecommons.org/licenses/by/2.0), which permits unrestricted use, distribution, and reproduction in any Medium, provided the original work is properly cited.
} 
also Encyclopedia of education defines "Inclination to like, to sick and to engage in certain kinds of activities."

Interests are the significant elements in personality, which play an important role in their educational and vocational careers. The tools for measuring the interest, like and dislike of an individual are various types of inventories, interest scale, records etc.

Two type of interest inventory:

1. For literate person

2. For illiterate person

Interest inventories indicate to extent to which the expressed interest of a person who are engaged in specific occupation.

\section{Types of Interest}

Interest is classified in following area:

1. Social Interest

2. Recreation Interest

3. Personal Interest

4. Vocational Interest.

\section{$>\quad$ Social Interest:}

Those interests by which a person sphere increase outside the home and neighborhood. He comes to contracts with more people.

\section{$>\quad$ Recreational Interest:}

Recreation contributes to mental health and the people who are healthy have specially this kind of interest. Especially adolescents have this kind of interest.

\section{$>\quad$ Personal interest:}

Every person, weather, boy or girl, adult or old, male and female has some kinds of personal interests.

\section{$>\quad$ Vocational Interest:}

Vocational interest are those by which person choose their vocation or want to take such vocation. The area of vocational is very large. A person alone cannot acquire all kinds of skill. Skill differs from person to person.

\section{Tests of Interest}

Tests of interest have been development by psychologist mainly for two purposes (a) to improve vocational selection in various jobs and (b) to provide vocational guidance for selecting appropriate vocation keeping in to consideration the individual's future success.

It has been very since research activities in the field of interest measurement in psychology started with growing interest. 
Froehlich has indicated the following four ways to obtain certain reliable information about the interests of the individual.

1. Observing the individual

2. Getting his expression of interest

3. Studying his activities he is engaging

4. Measuring the interest inventories.

In the field of applied psychology, these have appeared numerous "Inventories" to measure interest. Some of them:

$>\quad$ Kudder's preference record.

$>\quad$ Strong vocational interest blank.

$>\quad$ Thurston interest schedule.

$>\quad$ Minnesota vocational interest blank.

$>\quad$ Chatterji's non -verbal preference records.

$>\quad$ Bhardwaj's interest inventory.

All the above inventories, though different information ultimately aim of measuring the interest of the pupil with basic assumption that, measured interest reflect the needs, values and motivation of individual.

\section{Purpose:}

The purpose of study is to know the different type of interest of students in some different following areas.

Here, to know the interest to sample students, chatterji's non -language preference test was conduct on class X Govt. secondary school, kho-Nagorian, Jaipur (Raj).

\section{Brief Description Of The Preference Record :}

This chatterji's non-language preference record consists of 150 items and 3 pictures with each item. It measures the interest of everybody in ten broad interest areas.

Each item has three A, B, C, marked pictures. Students chooses a picture most liked and another picture least liked in each items. Most liked picture shows answer and least liked picture show negative answer.

There is no time limitation as has been prescribed in the manual C.N.P.R. 962.

\section{Descriptions Of Interest Factors And Area In Chatterji's Non-Language Test}

- FINE ARTS: Interest in photography, designing, painting, both playing and listing to music. 
- LITERARY WORK: Interest in reading, learning studying, teaching, anything to do with language and books.

- SCIENCE: Interest in physics, chemistry, Laboratory work, Astronomy, including both studying and teaching science.

- MEDICAL: Interest in being a doctor, nurse or hospital worker of some sort.

- AGRICULTURE: Interest in growing plants, caring for animal and using agricultural tool and Apparatus.

- TECHNICAL: Interest in s repairing mechanical and electrical apparatus .Working in factories also in scientific Laboratories.

- CRAFTS: Interest in working with your hands, making and fixing things.

- OUT DOORS: Interest in an active, outdoor life dislike for sedentary work, closed rooms, etc.

- SPORTS: Interest in sports and in leading an active life.

- HOUSE HOLD WORK: Interest in decorative and creative work. Other work knitting, sewing, cooking.

\section{Technical Information}

- $\quad$ Validity with (K.P.R.) $=+$.36 to .73 for different areas.

- $\quad$ Reliability

Table No.1 showing the reliability of ten C.N.P.R. 962 Scales calculated by using the Kuder Richardson Formula $21(N=1300)$

\begin{tabular}{|c|l|c|c|}
\hline S. No. & \multicolumn{1}{|c|}{ Field } & Reliability & Max .possible score \\
\hline 1 & Fine Arts & 0.85 & 88 \\
\hline 2 & Literary & 0.79 & 73 \\
\hline 3 & Scientific & 0.93 & 90 \\
\hline 4 & Medical & 0.95 & 91 \\
\hline 5 & Agricultural & 0.69 & 80 \\
\hline 6 & Technical & 0.86 & 78 \\
\hline 7 & Craft & 0.76 & 76 \\
\hline 8 & Outdoor & 0.93 & 90 \\
\hline 9 & Sports & 0.91 & 94 \\
\hline 10 & Household work & 0.81 & 84 \\
\hline
\end{tabular}

Table No. 1

Abbreviation used in different area and tables:

$\mathrm{RS}=$ Raw Scores, $\mathrm{S}=$ Stanine, $\mathrm{O}=$ Outdoor, $\mathrm{F}=$ Fine Arts, Ag=Agricultural, $\mathrm{C}=\mathrm{Crafts}$

$\mathrm{C}=$ Categories, $\mathrm{Lt}=$ Literary, $\mathrm{T}=$ Technical, $\mathrm{SP}=$ Sports, $\mathrm{SC}=$ Scientific, $\mathrm{HW}=$ Household $\mathrm{M}=$ Medical 
Material Required:

1. Booklet

2. Response Sheet

3. Scoring Key

4. Manual for interpretation

\section{Administration:}

Students were given a copy of Preference record and a copy of respond sheet. They were asked to read the direction given in the preference record booklet. Their difficulties if any, were solved, they were then to indicate their preference on the response sheet by putting a cross mark (x) in the appropriate place.

It was insured that students do their work independently. After completion of the test, answer sheets and booklets were collected.

\section{Scoring:}

The total number of crosses was written on the answer sheet in the space marked raw scores. Now the raw scores were converted into stanine scale with the help of Table-iii@ given on page 7 of the examiner Manual of CNPR-962. The stanine scale is a standardized scale of nine points. Its range is from 1 to 9 (lowest and highest) and their average is always 5.The name is derived from standard nine.

Table No. 2, Table shows raw scores in different area of Interest in the table for each subject.

\begin{tabular}{|c|c|c|c|c|c|c|c|c|c|c|c|}
\hline S.no & $\begin{array}{l}\text { Name of } \\
\text { students }\end{array}$ & F. & L. & SC & M. & A. & T. & C. & O. & SP & HW \\
\hline 1. & Bhanwar Lal & 25 & 25 & 37 & 46 & 19 & 30 & 27 & 12 & 23 & 26 \\
\hline 2. & Rajesh Gupta & 7 & 7 & 11 & 12 & 6 & 17 & 13 & 14 & 28 & 23 \\
\hline 3. & $\begin{array}{l}\text { Mahesh } \\
\text { Chandra }\end{array}$ & 20 & 23 & 20 & 20 & 15 & 22 & 19 & 19 & 17 & 26 \\
\hline 4. & Perm Chand & 29 & 29 & 24 & 23 & 19 & 29 & 26 & 27 & 17 & 21 \\
\hline 5. & Abdul Nasier & 23 & 24 & 24 & 27 & 11 & 15 & 15 & 40 & 45 & 25 \\
\hline 6. & Daya Shankar & 27 & 25 & 30 & 31 & 23 & 18 & 15 & 30 & 35 & 23 \\
\hline 7. & $\begin{array}{l}\text { Raton } \\
\text { LalBhati }\end{array}$ & 29 & 23 & 26 & 34 & 23 & 29 & 25 & 28 & 28 & 23 \\
\hline 8. & $\begin{array}{l}\text { Kuldeep } \\
\text { singh }\end{array}$ & 24 & 16 & 19 & 23 & 16 & 30 & 27 & 24 & 24 & 18 \\
\hline 9. & $\begin{array}{l}\text { Dinesh } \\
\text { Kumar }\end{array}$ & 26 & 17 & 14 & 24 & 27 & 29 & 30 & 36 & 43 & 23 \\
\hline 10. & Kamlesh Jain & 22 & 33 & 22 & 31 & 26 & 29 & 17 & 25 & 20 & 22 \\
\hline
\end{tabular}

(C) The International Journal of Indian Psychology, ISSN 2348-5396 (e)| ISSN: 2349-3429 (p) | 45 
Table No. 3, Showing the dividing points between various stanine in accumulated percentage

\begin{tabular}{lcc}
\hline Interpretation & Stanine Grades & Accumulated Percentage \\
High & 9 & $\begin{array}{l}\text { Above } 90 \% \\
\text { Above } 86 \% \text { and below } 96 \%\end{array}$ \\
$\begin{array}{l}\text { Above average } \\
\text { Above 77\% and below 86\% }\end{array}$ & 8 & $\begin{array}{l}\text { Above } 60 \% \text { and below } 77 \% \\
\text { Average }\end{array}$ \\
$\begin{array}{l}\text { Above40\% and below60\% } \\
\text { Below average }\end{array}$ & 6 & $\begin{array}{l}\text { Above23\% and below } 40 \% \\
\text { Above } 11 \% \text { and below } 23 \% \\
\text { Above } 4 \% \text { and below } 11 \%\end{array}$ \\
Low & 1 & Below $4 \%$
\end{tabular}

Table No. 4, Table shows raw scores converted in to stanine scale different area of Interest given below

\begin{tabular}{lllllllllllll|}
\hline S.no & \multicolumn{2}{l}{$\begin{array}{l}\text { Name of students } \mathbf{F} \text {. } \\
\text { HW }\end{array}$} & SC & M. & A. & T. & C. & O. & SP \\
1. & Bhanwar Lal & 2 & 6 & 2 & 6 & 5 & 2 & 6 & 1 & 1 & 2 \\
2. & Rajesh Gupta & 1 & 1 & 1 & 1 & 1 & 1 & 1 & 1 & 2 & 1 \\
3. & Mahesh Chandr 2 & 2 & 5 & 1 & 1 & 3 & 1 & 3 & 1 & 1 \\
4. & Pram Chand 3 & 7 & 1 & 2 & 5 & 1 & 5 & 2 & 1 & 1 \\
5. & Abdul Nasier 2 & 6 & 1 & 3 & 6 & 1 & 1 & 4 & 4 & 2 \\
6. & Daye Shankar 3 & 6 & 1 & 3 & 7 & 1 & 1 & 3 & 4 & 2 \\
7. & RatonLalBhati 2 & 3 & 5 & 1 & 2 & 7 & 1 & 5 & 5 & 2 \\
8. & Kuldeep Singh2 & 3 & 1 & 2 & 4 & 2 & 6 & 2 & 2 & 1 \\
9. & Dinesh Kumar 3 & 4 & 1 & 2 & 8 & 1 & 6 & 3 & 4 & 1 \\
10. & Kamlesh Jain 2 & 8 & 2 & 3 & 8 & 1 & 2 & 2 & 1 & 1
\end{tabular}

Table No. 5, Showing the 'rank of interest' of the each student in the subject (area) .

\begin{tabular}{lllll|}
\hline S.no & Name of students Low & \multicolumn{1}{c|}{ Below Average } & Average & Above Average High \\
\hline 1. & Bhanwar Lal & O,SP & F.SC.T.HW & A.L.M.C \\
2. & Rajesh Gupta & F.L.SC. & M.A.T. & SP \\
3. & MaheshChandra & SC.M.T.O.SP & F.HW.A.C. & L \\
4. & Pram Chand & SC.T.SP.HW & M.O.F & A.C. L. \\
5. & Abdul Nasier & SC.T.C. & F.HW.M & O, SP.L.A. \\
6. & Daye Shankar & SC.T.C. & HW.F.M.O. & SP.L.A. \\
7. & Raton LalBhati & SC.T. & M.O.SP.HW.F. & L.C. \\
8. & Kuldeep Singh & SC. HW. & F.M.T.O.SP.L. & A.C. A. \\
9. & Dinesh Kumar & SC.T.HW. & F.M.O. & L.SP.C. A. \\
10. & Kamlesh Jain & ST.SP.HW. & F.C.O. SC.M & L. A.
\end{tabular}




\section{ANALYSIS}

It was not possible to calculate the local norms in the form of stanine scores or Z-scores to interpret the result of student on different dimension of C.N.P.R.(962) because the test was administered on only ten students.

However it was found feasible to convert the raw scores with the help of manual norms, given for near most area for interpretation purpose. So norms given for different part of India in Table II (C ) page 7 of examiner's manual of C.N.P.R - 962 were consulted for evaluating the raw scores for standard ones. Stanine scores in different area of interest are given in Table II for each subject.

\section{Interpretation:}

Interpretation of results may be done in three ways:

* Individual Interest

* Group Interest

* Area Wise Interest

\section{Individual Interest :}

The raw scores of interest pattern of this student, converted into stanine scores, revealed that, his stanine scores are limited up to average rank. He is average in four areas i.e. agriculture, literacy, Medical, craft . It reveals that this student has average interest in these areas. His stanine scores are below average in fine - arts, scientific, technical, and household affairs. It reveals that he has hardly much interest in subjects related to these areas. He has got low stanine score in outdoor and sports.

It short, because he has got average marks in the four areas out of ten subject areas, it may be said that without obtaining supplementary information about aptitude of the child, suitable educational guidance cannot be provided.

\section{CASE- II:}

The raw scores of interest converted into stanine scores of this student reveal, that his stanine scores are limited up to below average rank. He has below average interest in sports. He is low in nine areas i.e. Fine arts, Literary, Scientific, Medical, Agricultural, Technical, Craft, Outdoor and Household affairs.

In short, that without obtaining supplementary information about aptitudes of the child, suitable educational guidance cannot be provided.

\section{CASE - III}

This student has got average scores in literary work. He has below average scores on Fine Arts, Household, Agricultural and craft. He has also got low marks on scientific, medical, technical, 
outdoor and sports work, therefore it can be said that he cannot make any progress in subject related to these areas.

\section{CASE - IV}

This student has got above average scores on literary. It reveals that the student is very much (not highly) interested in Literary area. Therefore, he cannot be recommended to study literary subjects. He has got average ranks on agricultural and crafts. He has got below average stanines on medical, outdoor and fine arts. He got low average score in scientific, technical, sports and household.

\section{CASE- V}

This student has got average ranking in four areas i.e.Outdoor, sports, literary and agriculture. It reveals that this student has average interest in these subject areas. His stanine scores are below average in Fine arts, Households and Medical. He has got low stanine scores in scientific, technical and crafts.

In short, because he has got average marks in these four areas out of ten subject areas, it may be said that without obtaining supplementary information about aptitudes of the child, suitable educational guidance cannot be provided.

\section{CASE-6}

This student has got average scores in three areas i.e. sports, literary and agricultural. It reveals that this student has average interest in these subject areas, literary and agriculture. It reveals that this student have average interest in these subject areas. He has got low statine scores in scientific, Technical and craft in short, because he has got average marks in the three areas out of the ten subject areas. It may be said that without obtaining supplementary information about aptitudes of the child, suitable educational guidance cannot be provided.

\section{CASE-7}

This student has got average scores on agriculture. . It reveals that this student is very much interested in agriculture. Therefore, he can be recommended to study agriculture subject. He has got average ranks in literary and craft. He has got below average marks on Medical, outdoor, sports, household and fine arts. He has got low stanine scores on scientific and technical areas.

\section{CASE-8}

This student has got average scores on agriculture and crafts. . He has got below average marks on the fine arts, Medical, technical, outdoor, sports, and literary work. He has got low stanine scores on scientific and household. Without obtaining supplementary information about aptitudes of the child, suitable educational guidance cannot be provided. 


\section{CASE-9}

This student has got average scores on agriculture. . It reveals that this student is very much (not highly) interested in agriculture. . Therefore, he can be recommended to study agriculture subject. . He has got average ranks on literary, sports, and craft area. He has got below average marks on Medical, outdoor, and fine arts. He has got low stanine scores on scientific and technical and household areas.

\section{CASE-10}

This student has got average scores on agriculture and literary areas. It reveals that this student is very much (not highly) interested in literary and agriculture area. Therefore, he can be recommended to study agriculture and literary subject. He has got below average scores on fine arts, outdoor, scientific medical and craft area. He has got low stanine scores on sports, technical and household.

Table No.6, Table shows overall picture of the Group Interest in different areas

\begin{tabular}{|l|l|l|l|l|l|l|l|l|l|l|l|}
\hline $\begin{array}{l}\text { Stanine } \\
\text { Grades }\end{array}$ & F & Lt & SC & M & Ag & T & C & O & Sp & Hw & Category \\
\hline ix & & & & & & & & & & & High \\
\hline Viii,vii & & 2 & & & 3 & & & & & $\begin{array}{l}\text { Above } \\
\text { Average }\end{array}$ \\
\hline Vi,v,iv & & 6 & & 1 & 5 & & 5 & 1 & 3 & & Average \\
\hline Iii, ii & 9 & 1 & 2 & 7 & 1 & 2 & 2 & 6 & 3 & 5 & $\begin{array}{l}\text { Below } \\
\text { average }\end{array}$ \\
\hline i & 1 & 1 & 8 & 2 & 1 & 8 & 3 & 3 & 4 & 5 & Low \\
\hline
\end{tabular}

Table-6 shows that group show high interest in agriculture and literary work. Group is average in craft.

Agriculture and literary also low average in scientific and technical.

\section{Area wise Interest}

If we rank the interest of group according to the grades in different area of interest on the basis of analysis, it may be concluded shows higher interest in Agriculture Literary and crafts and lower in scientific and Technical.

\section{CONCLUSION}

On the basis of above study we can say that interest of the group often students varies from one interest area to another. It shows the individual differences i.e. subjects show their interests in different areas. 
Administration, Scoring \& Interpretation of Interest Inventory- A Study on 10th Class Students (Jaipur)

\section{Acknowledgments}

The author appreciates all those who participated in the study and helped to facilitate the research process.

\section{Conflict of Interests}

The author declared no conflict of interests.

\section{REFERENCES}

John, p. Dececco, (1977). ” Psychology of learning and teaching” Prentice Hall India, New Delhi.

John.West,(1978) ”Research in Education “Prentice Hall (India) Ltd. New Delhi

Manual Chatterji’s Non Language Preference Record.(1960)

Robert, L. Ebel, (1969). “ Measuring Educational Achievement” Prentice Hall India, New Delhi

Stodola and Stodola, (1972). "Basic Education tests and Measurement' Thomson Press (India) Ltd. New Delhi

Sukhia, S.p. Mehrotra P.V. \& Mehrotra R.N.(1983). ”Elements of Educational Research Allied Publishers, New Delhi.

How to cite this article: V Joshi, S Joshi, M Joshi (2016), Administration, Scoring \& Interpretation of Interest Inventory- A Study on 10th Class Students (Jaipur), International Journal of Indian Psychology, Volume 4, Issue 1, No. 79, ISSN:2348-5396 (e), ISSN:2349-3429 (p), DIP:18.01.085/20160304, ISBN:978-1-365-56745-2 